\title{
Epimedium sagittatum inhibits TLR4/MD-2 mediated NF-KB signaling pathway with anti-inflammatory activity
}

\author{
Ni Yan', Ding-Sheng Wen², Yue-Rui Zhao ${ }^{1}$ and Shun-Jun $\mathrm{Xu}^{1,3^{*}}$
}

\begin{abstract}
Background: Epimedium sagittatum (Sieb.et Zucc.) Maxim., Ying-Yang-Huo in Chinese has been used as a traditional Chinese medicine and is deemed to "reinforce the kidney Yang". Previous studies showed that E. sagittatum could modulate the immune system and treat some chronic disease such as rheumatic arthritis, cardiovascular diseases and osteoporosis. The aim of this study is to evaluate the anti-inflammatory effects of ethyl acetate extracts (YYHs) of E. sagittatum and its mechanisms of action.
\end{abstract}

Methods: In order to explore the composition of YYHs, YYHs was analyzed using high performance liquid chromatography-mass spectrometry-mass spectrometry (HPLC-MS/MS) and in comparison with reference standards. Anti-inflammatory model was established in LPS-induced RAW264.7 cells. The levels of nitric oxide (NO) were measured with the Griess reagent. Production of tumor necrosis factor-alpha (TNF-a) and interleukin-2 (IL-2) were measured by enzyme-linked immunosorbent assays (ELISA). In addition, expression of p-p65 protein and TLR4/MD-2 complex was detected by western blots and flow cytometric, respectively. Nuclear factor kappa B (NF-kB) nuclear translocation was observed by fluorescence microscope.

Results: A total of eight compounds were identified, of which icariside II was the most abundant compound. YYHs $(12.5-50 \mu \mathrm{g} / \mathrm{mL})$ had no obvious cytotoxic effect on cells, and remarkably inhibited LPS-induced production of NO, TNF- $a$ and IL-2 with a dose-dependent manner. Additionally, YYHs up-regulated expression of p-p65 and TLR4/MD2 complex. Further research showed that YYHs significantly suppressed NF-kB p65 nuclear translocation.

Conclusion: In brief, YYHs contributed to the inhibition of LPS-induced inflammatory response through the TLR4/ MD-2-mediated NF-KB pathway and may be a potential choice to combat inflammation diseases.

Abstract graph: It includes a schema of pathways at the end of the paper.

Keywords: E, sagittatum, Anti-inflammation, TLR4/MD-2, NF-KB

\section{Background}

Inflammation acts physiologically to protect normal host function after pathogen invasion or tissue damage [1]. As a major virulence factor of Gram-negative bacteria, LPS induces a serious systemic inflammatory response in macrophage [2]. TLR4 plays a key role for innate immune responses and its signaling is triggered by the transfer of its ligand LPS to a Toll-like receptor 4/myeloid differentiation

\footnotetext{
* Correspondence: shjxu2002@hotmail.com

'Department of Research and Development, ImVin Pharmaceutical Co., Ltd, 2 Fangcaodian Road, Guangzhou 510663, China

${ }^{3}$ Zhuhai Jizhu Small and Medium Enterprises Advanced Technology Research Institute, Zhuhai College of Jilin University, Zhuhai 519041, China Full list of author information is available at the end of the article
}

factor-2 (TLR4/MD-2) complex, which then undergoes homodimerization [3]. Thus, the TLR4/MD-2 complex constitute the indispensable components of the LPS receptor system and have been implicated in inflammation. Binding of the TLR4/MD-2 complex to LPS triggers the activation of JNK and NF- $\mathrm{kB}$ signaling pathway [4]. During inflammatory processes, LPS stimulates the production of the pro-inflammatory cytokines and inflammation mediators, such as TNF- $\alpha$, IL-2 and nitric oxide (NO). However, inflammation persistently produces pro-inflammatory cytokines and inflammatory mediators that eventually evolves into excess inflammation, which is closely associated with many diseases including cancer [5], Alzheimer's disease [6],

(c) The Author(s). 2018 Open Access This article is distributed under the terms of the Creative Commons Attribution 4.0 International License (http://creativecommons.org/licenses/by/4.0/), which permits unrestricted use, distribution, and 
obesity and diabetes [7]. In addition, extensive studies supported that anti-inflammatory therapy is efficacious to slow the progression and delay the onset of these disease.

Nuclear factor- $\mathrm{kB}(\mathrm{NF}-\mathrm{kB})$ is a transcription factor that is essential for inflammation, immunity, cell proliferation and apoptosis [8]. There are two NF- $\mathrm{BB}$ signaling pathway including the classical and the alternative pathway, of which the classical attracts more attention. The classical pathway of NF- $\mathrm{kB}$ is triggered by pro-inflammatory cytokines and LPS. Subsequently, inhibitory protein IкB- $\alpha$ and p65 are phosphorylated, meanwhile, inhibitory molecule is degraded by proteasome-mediated. Then, the heterodimer p50/p65 is released and migrats from the cytoplasm to the nucleus to regulate the expression of multiple target genes, such as TNF- $\alpha$, IL-6, iNOS and so on $[9,10]$.

Epimedium sagittatum (Sieb.et Zucc.) Maxim., a tranditional herbal drug in China, widely grows in Guangdong, Guangxi and Jiangxi province. And it contains flavonoids, lignans and so forth. Specially, major secondary metabolites of $E$. sagittatum, in which mainly includes epimedin A, B, C and icariin [11]. Species of Epimedium have four members according to the Chinese Pharmacopoeia, they are E. brevicornu Maxim., E. sagittatum (Sieb.et Zucc.) Maxim., E. pubescens Maxim. and E. koreanum Nakai [12]. Previous studies showed that the species of Epimedium exhibited many bioactivities, such as antiviral [13], antinociceptive [14], anti-aging [15], antioxidant, neurotective effect [16], enhancing immunity [17] and promoting estrogen biosynthesis [18]. However, there are few reports about the biological activity of E. sagittatum, especially in terms of anti-inflammatory.

The objective of this study is to analyze constituent and evaluate the anti-inflammatory activity of YYHs by LPS stimulated RAW 264.7 cells model. Besides, we tried to explore the anti-inflammation mechanism via the TLR4/MD-2-mediated NF-kB signaling pathway.

\section{Methods}

\section{Preparation of extract}

The dried material was from Guangdong province and provided by ImVin Pharmaceutical Co., Ltd. (Guangzhou, China). The authentication of plant materials was finished by professor Dingping (Guangzhou University of Chinese Medicine). At first, the herb of $\mathrm{YYH}$ was powdered and heat extracted three times with 10 -fold of $50 \%$ ethanol at $70{ }^{\circ} \mathrm{C}$ for $25 \mathrm{~min}$. After cooling, the solution was filtered and removed ethanol, followed by separations with ethyl acetate $(v / v=1: 1)$. The YYH extracted ethyl acetate fraction was concentrated by rotary evaporation (EYELA, Japan) and stored at $-20^{\circ} \mathrm{C}$ before use.

\section{Chemicals and reagents}

3-(4,5-dimethylthiazol-2-yl)-2,5-diphenyltetrazoliumbromide (MTT), Griess reagent and bacterial lipopolysaccharide
(LPS) were acquired from Sigma Chemical Co. (St Louis, MO, USA). Fetal bovine serum (FBS) was purchased from Life Technologies (Auckland, New Zealand). Dulbecco's Modified Eagle's Medium (DMEM), Penicillin-streptomycin solution, Dulbecco's Phosphate Buffered Saline (DPBS), GlutaMAX ${ }^{\mathrm{m}}-1$ and $0.25 \%$ Trypsin-EDTA were obtained from Hyclone (Logan, Utah, USA). PE-conjugated rat anti-mouse TLR4/MD-2 complex (clone MTS510) and rat IgG2a kappa isotype control antibodys were products of eBioscience (San Diego, CA, USA). Mouse TNF- $\alpha$ and IL-2 ELISA kits were acquried from Neobioscience Technology Co., Ltd. (Beijing, China). NF-kB Activation -Nuclear Translocation Assay kit from Beyotime Institute of Biotechnology (Nanjing, China). Rabbit phospho-NF- $\mathrm{kB}$ (Ser536) antibody and rabbit NF- $\mathrm{kB}$ p65 (C22B4) antibody from Cell Signaling Technology (Danvers, MA) were also obtained. Epimedin $\mathrm{C}$ and icariin were provided by the National Institute for Food and Drug Control (Beijing, China). Epimedin B was purchased from Herbest (Baoji, China). Baohuoside II and Baohuoside VII were obtained from Chem Faces (Wuhan, China). All standards had a purity of $98 \%$.

\section{HPLC and LC-MS/MS conditions}

Chromatographic separation (Agilent 1100 HPLC system) was achieved on an Agilent Zorbax SB-C18 column $(250 \times 4.6 \mathrm{~mm}, 5 \mu \mathrm{m})$. The mobile phase consisted of acetonitrile as solvent $\mathrm{A}$, methanol as solvent $\mathrm{B}$ and $0.5 \%$ acetic acid in water as solvent $\mathrm{C}$. The gradient of mobile phase was shown in Table 1. The flow rate was $1 \mathrm{~mL} / \mathrm{min}$, and the column temperature was set at $20^{\circ} \mathrm{C}$. The diode-array detection was set to monitor at $270 \mathrm{~nm}$. The mass spectrometry analysis was performed on a LTQ-Orbitrap XL mass spectrometer (Thermo Electron, Bremen, Germany) coupled with an ESI source, and used with the following conditions: source temperature: $350{ }^{\circ} \mathrm{C}$; ion spray voltage - $4.5 \mathrm{kV}$; Gas 1, Gas 2,curtain gas, and collision gas (nitrogen) were separately set at 50, 50, 45, and $12 \mathrm{psi}$; sheath gas flow rate, 40 arbitrary units; auxiliary gas flow rate, 5 arbitrary units; electrospray voltage, $3.5 \mathrm{kV}$; capillary voltage, $-32 \mathrm{~V}$; capillary temperature, $270{ }^{\circ} \mathrm{C}$.

Table 1 Mobile phase condition of chromatographic separation

\begin{tabular}{llll}
\hline Time (min) & Acetonitrile (\%) & Methanol (\%) & $\begin{array}{l}0.5 \% \text { acetic acid } \\
\text { in water (\%) }\end{array}$ \\
\hline $0-30$ & $12-25$ & 0 & $88-75$ \\
$30-45$ & $25-23.5$ & $0-11$ & $75-65.5$ \\
$45-68$ & $23.5-35$ & $11-4$ & $65.5-61$ \\
$68-85$ & 35 & 4 & 61 \\
$85-90$ & $35-50$ & $4-0$ & $61-50$ \\
$90-95$ & 100 & 0 & 0 \\
$95-110$ & 100 & 0 & 0 \\
\hline
\end{tabular}




\section{Cell culture and viability assay}

RAW 264.7 cells were obtained from American Type Culture Collection (Manassas, VA, USA) and cultured in DMEM which was supplemented with $10 \%$ FBS, 1\% penicillin-streptomycin solution and $1 \%$ GlutaMAX ${ }^{\mathrm{si}}-1$ at $37{ }^{\circ} \mathrm{C}$ in a humidified incubator containing $5 \% \mathrm{CO}_{2}$. Cells were seeded in 96-well plates at a density of $1 \times$ $10^{5}$ cells $/ \mathrm{mL}$ and incubated for $24 \mathrm{~h}$. They treated with different concentrations of YYHs $(12.5,25,50,75 \mu \mathrm{g} / \mathrm{mL})$ in the absence or presence of $1 \mu \mathrm{g} / \mathrm{mL}$ LPS for $24 \mathrm{~h}$, respectively. Then, $50 \mu \mathrm{L}$ MTT solution $(0.5 \mathrm{mg} / \mathrm{mL}$ in DPBS) was added to plates and incubated for $4 \mathrm{~h}$ in the incubator. After incubation finished, the supernatants was discarded and replaced with DMSO $(200 \mu \mathrm{L})$ to dissolve the formazan crystal. The absorbance of each well was detected at $570 \mathrm{~nm}$ using a microplate reader (BERTHOLD Technologies, Germany).

\section{Nitric oxide (NO) and enzyme-linked immunosorbent assay}

To assay the production of NO, IL- 2 and TNF- $\alpha$, the supernatant of RAW 264.7 cells was collected after co-treated with YYHs $(12.5,25,50 \mu \mathrm{g} / \mathrm{mL})$ and LPS $(1 \mu \mathrm{g} / \mathrm{mL})$ for $24 \mathrm{~h}$. The IL-2 and TNF- $\alpha$ were determined using enzyme-linked immunosorbent assay kits according to the manufacturer's instructions. Meanwhile, the NO production was determined by mixing $100 \mu \mathrm{L}$ of the supernatant with an equal volume of Griess reagent comprising $50 \mu \mathrm{L}$ of $2 \%$ sulfanilamide in $4 \%$ phosphoric acid and $50 \mu \mathrm{L}$ of $0.2 \% \mathrm{~N}$-(1-naphthyl) -ethylenediamine dihydrochloride in water for $10 \mathrm{~min}$ at room temperature, and the concentration of nitrite was determined by using a standard curve generated with sodium nitrite under a spectrophotometer on a wavelength of $550 \mathrm{~nm}$.

\section{Flow cytometric analysis}

RAW 264.7 cells treated with YYH extracts (12.5, 25 and $50 \mu \mathrm{g} / \mathrm{mL})$ and LPS $(1 \mu \mathrm{g} / \mathrm{mL})$ for $18 \mathrm{~h}$ were harvested with $0.25 \%$ trypsin and washed with PBS by centrifugation for $5 \mathrm{~min}$. Subsequently, cells were incubated with a PE-conjugated anti-mouse TLR4/MD-2 complex antibody and FITC-conjucted anti-mouse CD14 or PE/ FITC-conjugated IgG as isotype control for $30 \mathrm{~min}$ at $4{ }^{\circ} \mathrm{C}$, respectively. The cell surface makers expression was analyzed by Attune acoustic focusing cytometer (Thermo Fisher Scientific, USA). The data of MFI value were calculated the levels of fluorescence by Flow Jo software (FlowJo LLC, USA).

\section{Nuclear factor-KB (NF-KB) nuclear translocation assay}

The activation of NF- $\mathrm{kB}$ nuclear translocation was detected by using NF- $\mathrm{kB}$ activation nuclear translocation assay kit according to the manufacturer's protocol. Briefly, cells were pretreated YYHs $(50 \mu \mathrm{g} / \mathrm{mL})$ for $1 \mathrm{~h}$ prior to incubation with LPS for another $1 \mathrm{~h}$, together. After fixing and permeabilizing, the cells were incubated with a blocking solution for $1 \mathrm{~h}$, followed by NF-kB p65 antibody at $4{ }^{\circ} \mathrm{C}$ overnight. Next, after washing three times, cells incubated with a Cy3-conjugated secondary antibody for $1 \mathrm{~h}$, then with DAPI for 5 min before observation. The activation of NF- $\mathrm{kB}$ p 65 was visualized with a fluorescence microscope (Axiovert $40 \mathrm{CFL}$, Carl Zeiss) at excitation wavelength of $350 \mathrm{~nm}$ for DAPI and $540 \mathrm{~nm}$ for $\mathrm{Cy} 3$, and the red and blue images were overlaid by Image-pro plus 5.1 software to indicated the areas of co-localization.

\section{Western blot assay}

RAW 264.7 cells $\left(7.5 \times 10^{5}\right.$ cells $\left./ \mathrm{mL}\right)$ were seeded in 6 -well plates for $24 \mathrm{~h}$. Then, cells orderly incubated with YYHs $(2 \mathrm{~h})$ and LPS $(1 \mathrm{~h})$. The total proteins, extracted with cell lysis buffer (RIPA:PMSF: Phosphatase inhibitor $=100: 1: 1$ ) by ultrasonic, were quantified using a BCA protein assay kit. An equal amount of protein $(25 \mu \mathrm{g})$ was separated on $10 \%$ SDS-PAGE for electrophoresis, followed by transfer to PVDF membranes. Then, the membranes were severally blocked with $5 \%$ non-fat milk or $5 \%$ BSA for $1 \mathrm{~h}$ and then incubated with primary antibodies (1:1000 dilution) overnight at $4{ }^{\circ} \mathrm{C}$. The following day, membranes were incubated with a horseradish peroxidase-conjugated goat anti-rabbit antibody (1:1000 dilution) for $2 \mathrm{~h}$ and detected by enhanced chemiluminescence (ECL). Protein levels were normalized against included $\beta$-actin standards and analyzed by Image J software.

\section{Statistical analysis}

All experiments were performed at least three times and expressed as mean \pm standard deviation (S.D). The differences between groups were analyzed by one-way ANOVA, followed by a Tukey's test using SPSS 20.0 software (SPSS Inc., Chicago, USA). $P$ value of 0.05 or less was considered as statistically significant.

\section{Results}

\section{Measurement of major compounds of YYHs}

A total of eight chromatographic peaks were identified five of which were assigned by comparison with reference standards, three of which were characterized based on their chromatographic behavior and MS/MS fragmentation pattern. As shown in Fig. 1 and Table 2, sagittatoside B $\left([\mathrm{M}-\mathrm{H}]^{-} \mathrm{m} / z\right.$ at 645.21472 ; error $\left.\mathrm{ppm}=4.746\right)$, 2"-O-rhamnosyl icariside II $\left([\mathrm{M}-\mathrm{H}]^{-} \mathrm{m} / \mathrm{z}\right.$ at 659.23071 ; error $\mathrm{ppm}=4.129)$ and icariside II $\left([\mathrm{M}-\mathrm{H}]^{-} \mathrm{m} / z\right.$ at 513.17407; error $\mathrm{ppm}=2.832$ ) were detected by LC-MS/ MS. Epimedoside C, icariin, icariside II and 2"-O-rhamnosyl Icariside II were the major compounds of YYHs, which were $9.59,18.89,30.94$ and $7.97 \%$, respectively. 


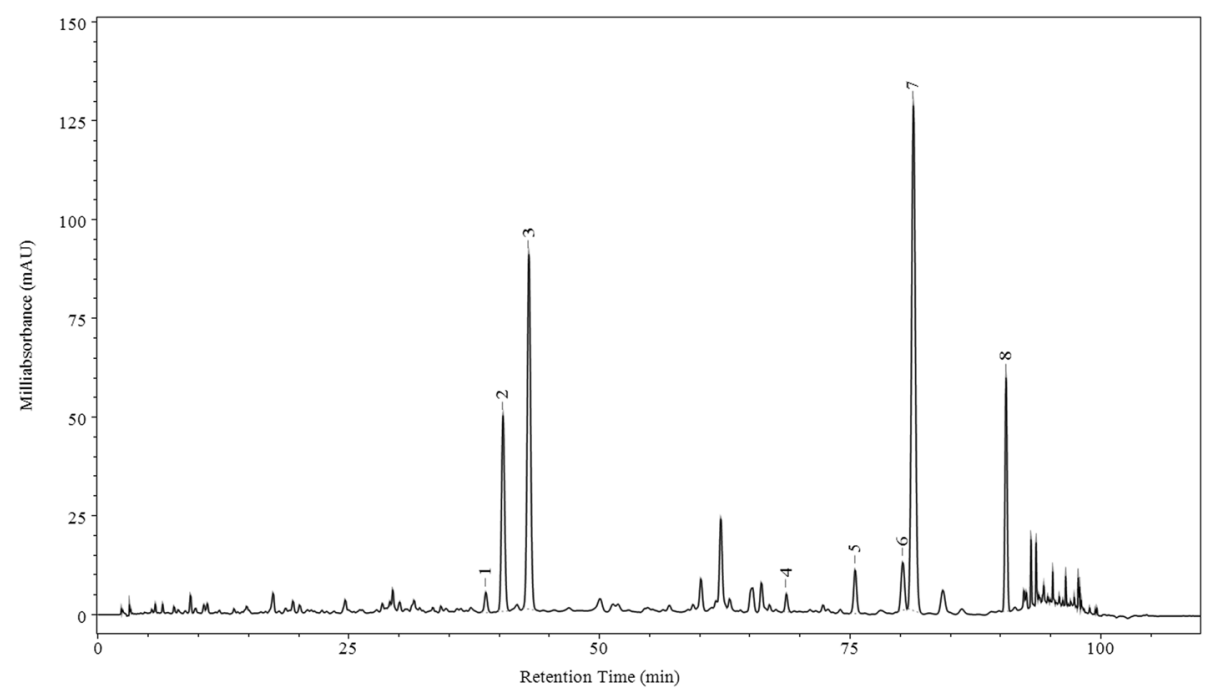

Fig. 1 Representative HPLC chromatogram of YYHs at $270 \mathrm{~nm}$

\section{Cytotoxicity of YYHs on viability of cells}

The MTT assay was carried out to estimate the cytotoxicity of YYHs on RAW 264.7 cells. As the results shown in Fig. 2, the presence of LPS $(1 \mu \mathrm{g} / \mathrm{mL})$ had no impact on cell viability, expectedly. Then, exposure of cells to $(12.5-50 \mu \mathrm{g} / \mathrm{mL})$ YYHs with $1 \mu \mathrm{g} / \mathrm{mL}$ LPS for $24 \mathrm{~h}$ showed no cytotoxicity. However, when the cells were treated with $75 \mu \mathrm{g} / \mathrm{mL}$ YYHs and $1 \mu \mathrm{g} / \mathrm{mL}$ LPS, the cell viability was less than $50 \%$. Therefore, all subsequent experiments were performed at nontoxic concentrations $(12.5-50 \mu \mathrm{g} / \mathrm{mL})$.

\section{Effect of YYHs on levels of NO, TNF-a and IL-2}

We first investigated the anti-inflammatory activity of YYHs. Treatment of LPS for $24 \mathrm{~h}$ can lead to inflammatory response on RAW 264.7. During inflammation, a large amount of NO and pro-inflammatory cytokines including TNF- $\alpha$ and IL-2 were generated. YYHs at dose of $50 \mu \mathrm{g} / \mathrm{mL}$ significantly

Table 2 The main components of YYHs

\begin{tabular}{llll}
\hline Peak & $\begin{array}{l}\text { Retention } \\
\text { time (min) }\end{array}$ & Component & Concentration (\%) \\
\hline $1^{\mathrm{a}}$ & 38.664 & Epimedoside B & 0.90 \\
$2^{\mathrm{a}}$ & 40.376 & Epimedoside C & 9.59 \\
$3^{\mathrm{a}}$ & 42.963 & Icariin & 18.89 \\
$4^{\mathrm{a}}$ & 68.647 & Baohuoside II & 0.70 \\
$5^{\mathrm{a}}$ & 75.499 & Baohuoside VII & 2.07 \\
6 & 80.248 & Sagittatoside B & 2.94 \\
7 & 81.308 & 2"-O-Rhamnosy & 30.94 \\
8 & & (Icariside II) & \\
\hline
\end{tabular}

$(1-5)^{a}$ were assigned by comparison with reference standards. (6-8) were identified by MS/MS decreased the levels of TNF- $\alpha$ and IL-2 with inhibition values of $50.89 \pm 3.55 \%$ and $55.38 \pm 7.60 \%$ (Fig. 3A, B). Furthermore, YYHs concentration-dependently suppressed the production of NO (Fig. 3C).

\section{Effect of YYHs on cell surface of TLR4/MD-2 complex in cells}

The TLR4/MD-2 complex was critical for LPS recognition and innate immune response. To assess the effect of YYHs on the formation of TLR4/MD-2 complex, we detected the expression of the complex by flow cytometry. As shown in Fig. 4, The plenty of TLR4/MD-2 complex were formed after LPS stimulated cells, and treatment of

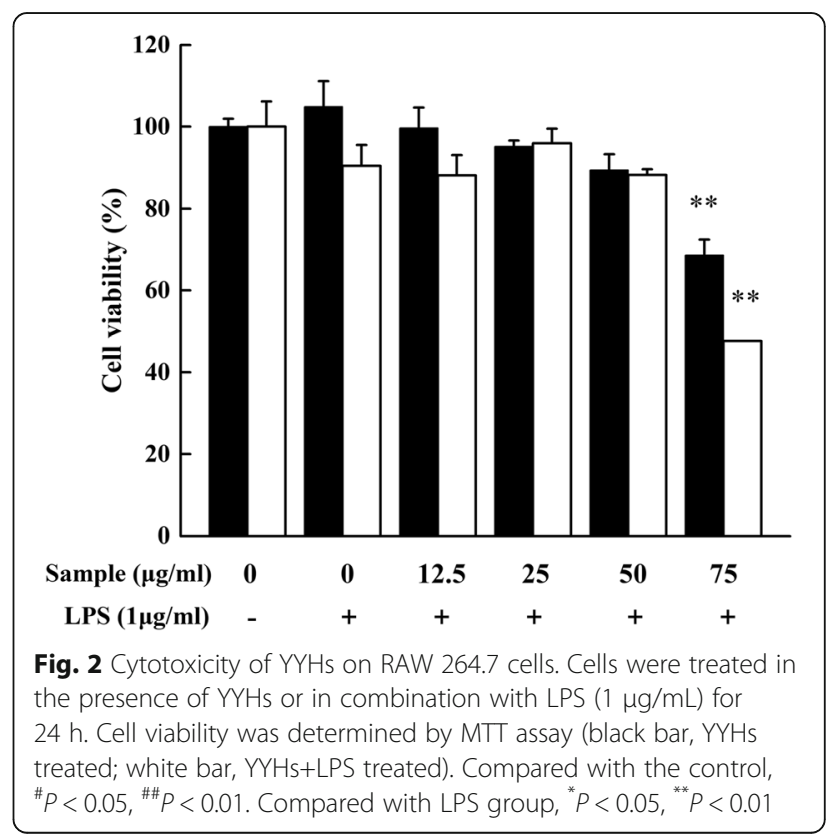




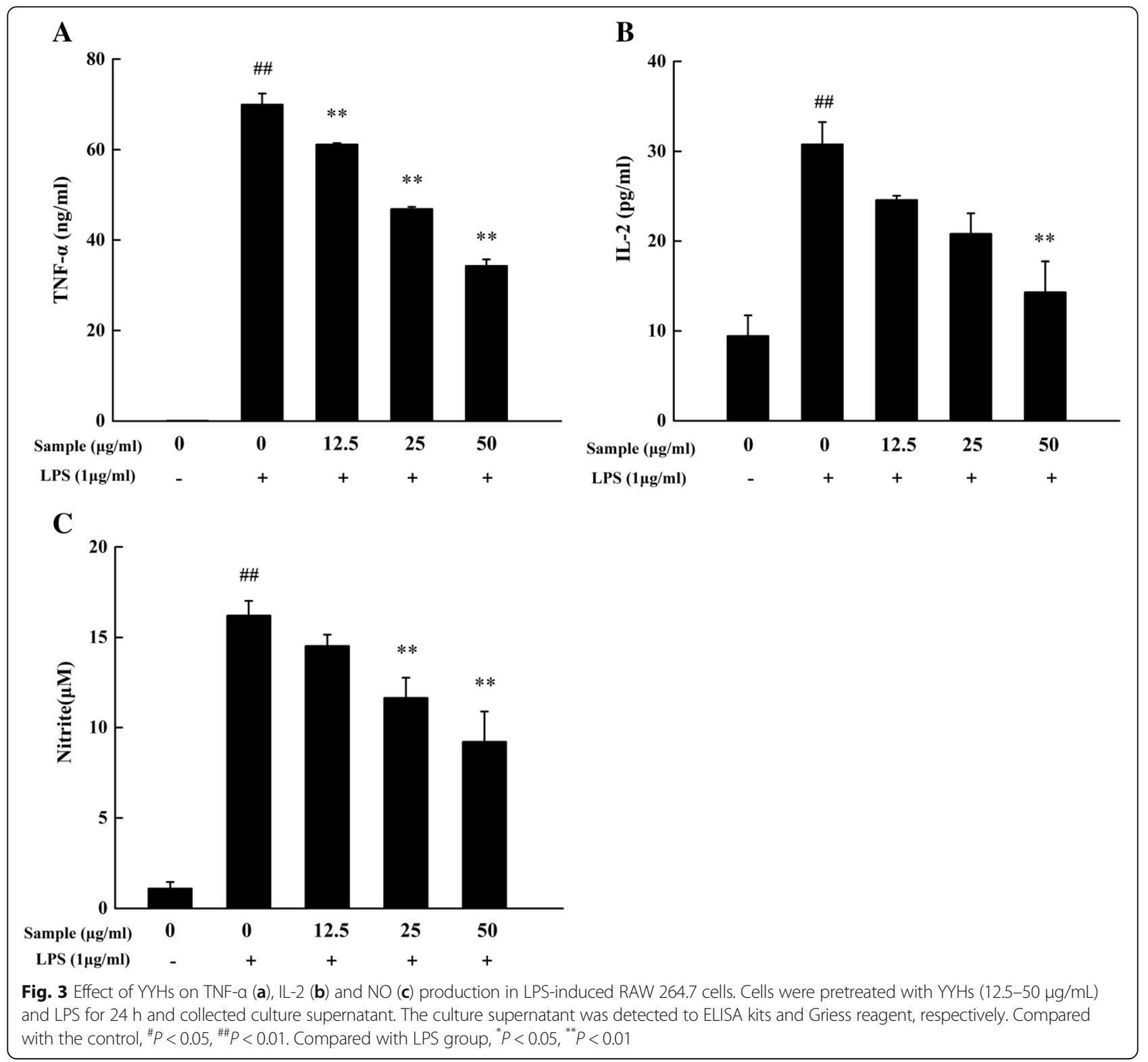

YYHs can interrupt the formation of the TLR4/MD-2 complex in a concentration-dependent manner. When the concentration of $50 \mu \mathrm{g} / \mathrm{mL}$, TLR4/MD-2 complex obviously decreased more than half as LPS group.

\section{Effect of YYHs on the nuclear translocation and phosphorylation of p65 in cells}

As an important upstream transcription factor, NF- $\mathrm{kB}$ regulated expression of $\mathrm{NO}$ and .pro-inflammatory cytokines by LPS stimulation. Translocation of NF- $\mathrm{kB}$ p 65 into the nucleus were increased within $1 \mathrm{~h}$ after LPS stimulation, as compared with control groups (Fig. 5). However, pre-treatment with YYHs $(50 \mu \mathrm{g} / \mathrm{mL})$ for $1 \mathrm{~h}$ markedly suppressed NF-kB p65 levels in the nucleus. Meanwhile, we explored the effect of YYHs on LPS induced NF-kB p65 phosphorylation by western blot analysis. Compared to the unstimulated cells, LPS expectedly induced phosphorylation of p65. Treatment with different concentration of YYHs attenuated phosphorylation of p65 in a dose-dependent manner (Fig. 6). These results strongly suggested that YYHs down-regulated the LPS-induced phosphorylation of $\mathrm{p} 65$.

\section{Discussion}

Traditionally, the leaves of Epimedium had long been used as a kidney tonic and antirheumatic for more than 2000 years [19]. In recent years, it was also used to treat various diseases, such as parkinson's disease [20], rheumatic arthritis [21], osteoporosis [22, 23] and asthma [24]. Virtually, most of the attention focused on E. brevicornu 

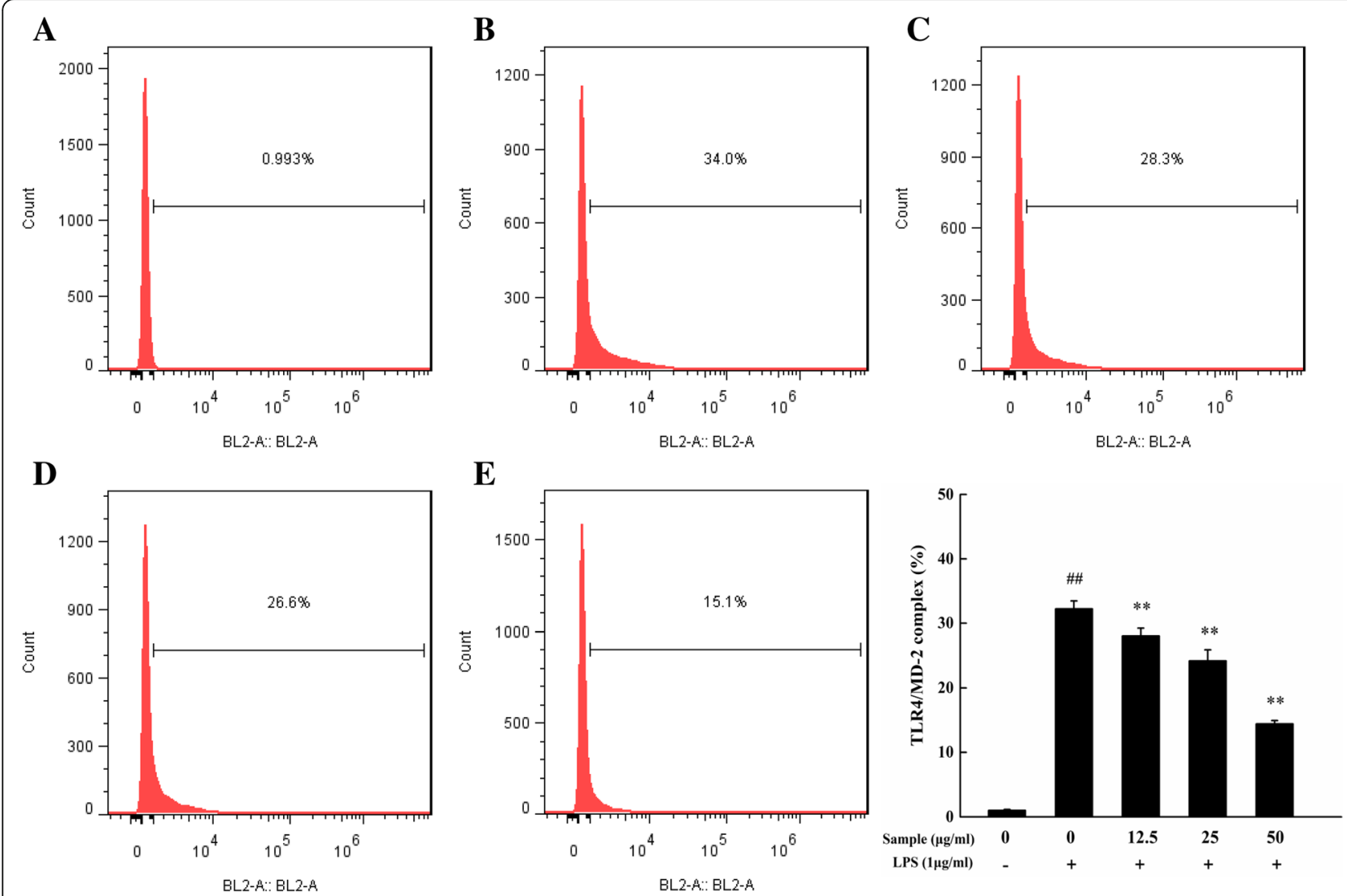

Fig. 4 Flow cytometric analysis for TLR4/MD-2 complex. Cells were treated with YYHs and LPS (1 $\mu \mathrm{g} / \mathrm{mL})$ for $18 \mathrm{~h}$. And TLT4/MD-2 complex was detected with FCM by PE conjugated mAb TLR4/MD-2 complex antibody (a, blank group; b, LPS group; c-e, 12.5-50 $\mu \mathrm{g} / \mathrm{mL}$ YYHs group). Compared with the control, ${ }^{\#} P<0.05,{ }^{\# \#} P<0.01$. Compared with LPS group, ${ }^{*} P<0.05,{ }^{* *} P<0.01$

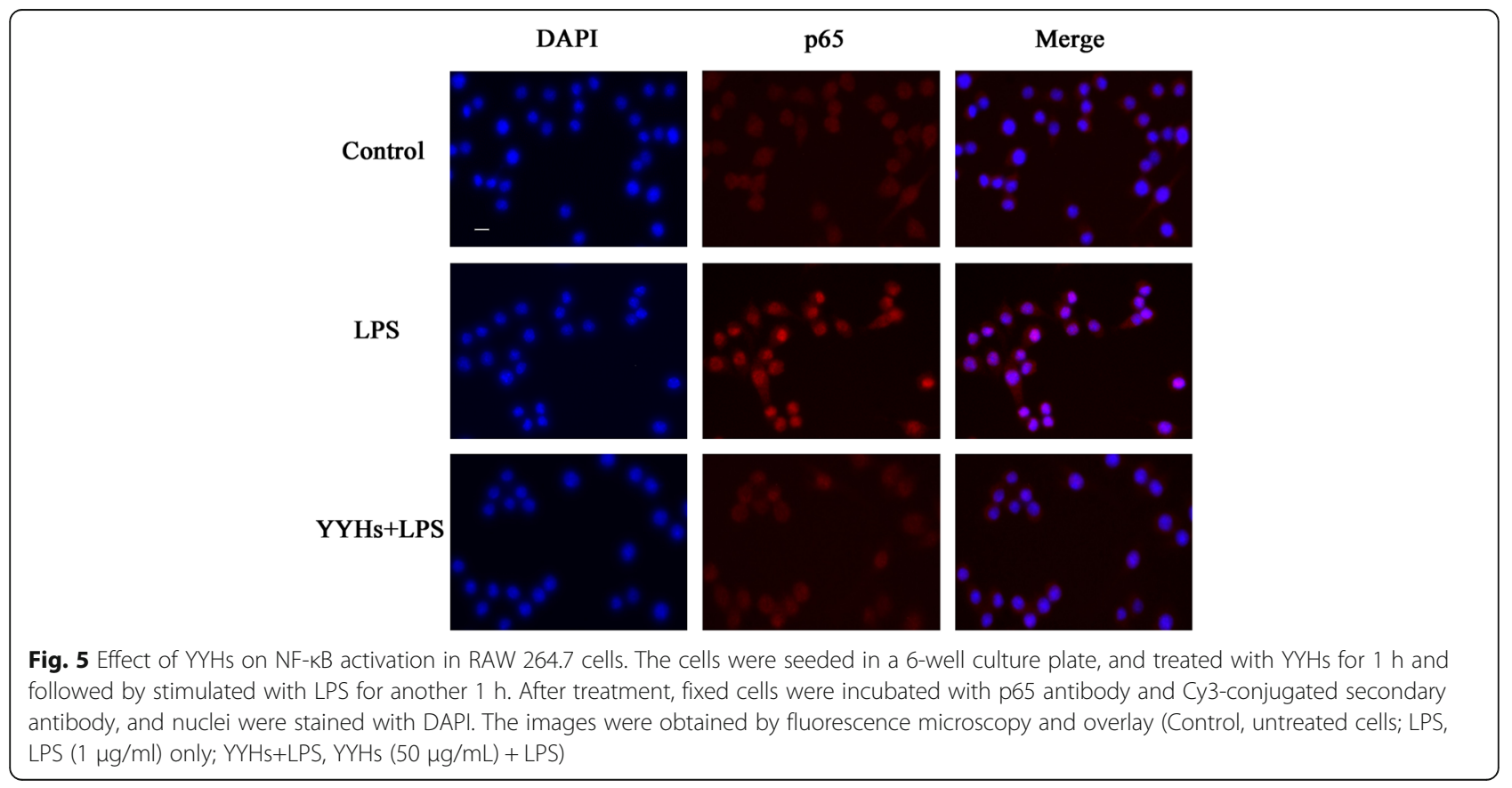




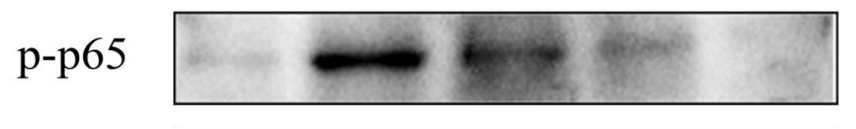

p65

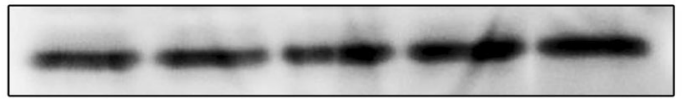

$\beta$-actin

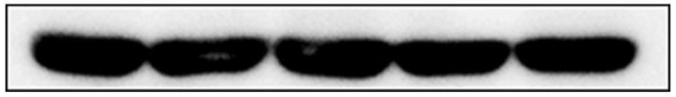

$\begin{array}{cccccc}\text { Sample }(\mu \mathrm{g} / \mathrm{ml}) & 0 & 0 & 12.5 & 25 & 50 \\ \operatorname{LPS}(1 \mu \mathrm{g} / \mathrm{ml}) & - & + & + & + & +\end{array}$

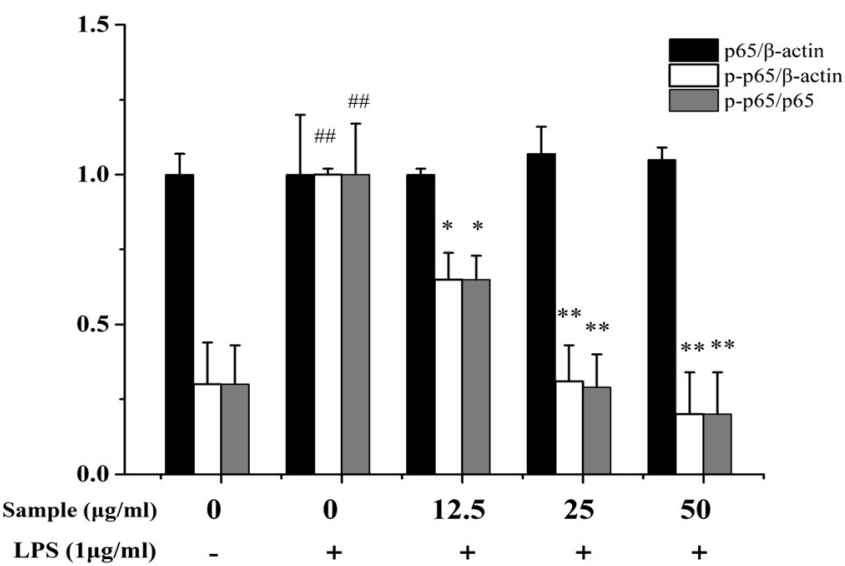

Fig. 6 Effect of YYHs on LPS-induced activation of NF-KB pathway in RAW 264.7 cells. The cells were pretreated with different concentrations of YYHs for $2 \mathrm{~h}$ and then stimulated with LPS $(1 \mu \mathrm{g} / \mathrm{mL})$ for another $1 \mathrm{~h}$. The NF-KB p65 and phosphorylated p65 in the total protein was detected by western blotting. $\beta$-acting was used as the internal control for normalization. Compared with the control, ${ }^{\#} P<0.05,{ }^{\# \#} P<0.01$. Compared with LPS group, ${ }^{*} P<0.05,{ }^{* *} P<0.01$

Maxim and E. koreanum Nakai. In this study, Enzyme-linked immunosorbent assay, flow cytometric analysis and western blot assay which were performed under different YYHs exposure time was according to the references described as previous [4, 25]. However, it was found that a small proportion of the cells in the 6-well plate were shed $24 \mathrm{~h}$ post stimulated with LPS under the premise of the same cell plating density, when shortening the stimulation time of co-treatment to $18 \mathrm{~h}$, there was no sheding of cells. So we the exposure different time was employed in assays. Finally, the results showed YYHs distinctly decreased production of NO, TNF- $\alpha$ and IL-2, and markedly suppressed the expression of TLR4/MD-2 complex and NF-kB p65 nuclear translocation, which implied YYHs had anti-inflammatory activity on LPS-induced inflammatory responses.

In our study, YYHs were detected by HPLC system. Among the components, 2"-O-rhamnosyl icariside II was the richest component (30.94\%) in ethyl acetate fraction. As a prenylated flavonol glycosides, 2"-O-rhamnosyl icariside II was isolated from Epimedium koreanum Nakai for the first time in 1991 [26]. Additionally, icariin (18.89\%), epimedoside C (9.59\%) and icariside II (7.97\%) are relatively abundant in the extracts, and it is known to all that those were some major bioactive components in Herba Epimedii. Icariin exerted its anti-inflammatory effect mainly through modulating glucocorticoid receptor function and inhibiting the pro-inflammatory transcription factors including TNF- $\alpha$, IL-6, IL-8 and MMP-9 [27, 28]. Previous studies demonstrated that icariin protected dopamine neurons against neurotoxins-induced neurotoxicity and inhibited pro-inflammatory factors production via the NF- $\mathrm{kB}$ signaling pathway, in which might be compactly associated with the inhibition of microglia-mediated neuroinflammation [29]. Furthermore, Icariside II also possibly suppressed neuroinflammation by reducing expression of IL- $1, \mathrm{IL}-1 \beta$, TNF- $\alpha$, COX-2, and iNOS mRNA and protein, which eventually reversed A $\beta$-induced cognitive deficits [30]. Through rat model of experimental autoimmune encephalomyelitis (EAE), researchers found that epimedium flavonois (icaiin accounting for $56.7 \%$ and epimedin C 20.6\%) can alleviate demyelination and inflammatory infiltration [31].

$\mathrm{NO}$ is a relatively short -lived free radical, which participates in physiological processes and is synthesized by nitric oxide sythase (NOS) and L-Arginine. NOS divides into three isoforms, such as inducible NOS (iNOS), 
endothelial NOS (eNOS) and neuronal NOS (nNOS), of which iNOS mainly regulate inflammation responses $[25,32]$. It is well-know that inflammation response by secreting inflammatory mediator and pro-inflammatory cytokines could be caused by the stimulation of LPS. Overproduction of NO and TNF- $\alpha$ may lead to DNA damage by oxidative stress and DNA mutation [33-36]. In addition, there are several evidences that IL-2 has an association with chronic inflammation by modulating production of the pro-inflammatory cytokine (IFN- $\gamma$ ) [37]. In our study, we found that treatment of YYHs effectively modulated NO production and attenuates the expression of TNF- $\alpha$ and IL-2 in active macrophages (Fig. 3). And it means YYHs may be a valuable anti-inflammatory agent.

According to the crystal structure research, multiple structural components of TLR4/MD-2 are involved in LPS recognition [38]. TLR4/MD-2 complex as the main LPS binding receptors, it responds to inflammatory stimuli as well as mediate NF- $\mathrm{kB}$ signaling pathway in macrophages. For example, Zhankuic acid A contributes to the regulation of inflammatory responds through TLR4/MD-2 mediating MAPK and NF- $\mathrm{kB}$ pathway, which the same applies to procyanidin B1 and Baicalein [39-41]. NF-кB is critical downstream target of TLR4/ MD-2 pathway and adjusts the expression of pro-inflammatory and inflammatory mediator genes [42]. Previous studies revealed that apigenin was attributed to decreasing production of IL- 6 , IL- $1 \beta$ and TNF- $\alpha$ through the inhibition of NF- $\kappa B$ activation [43]. Besides, indirubin also effectively suppressed LPS-induced inflammation through the NF-kB pathway [44]. Similarly, we demonstrated that YYHs actively ameliorated the inflammatory responses induced by LPS. Finally, YYHs inhibited the formation of TLR4/MD-2 complex (Fig. 4), which subsequently down-regulated the phophorylation of p65 (Fig. 6) and restrained translocation of p65 into the nucleus (Fig. 5).

\section{Conclusions}

In summary, YYHs from E.sagittatum remarkedly decreased the production of inflammatory mediator and pro-inflammatory cytokines in LPS-induced RAW264.7 cells, and that interacted with TLR4/MD-2 complex formation to block LPS action. Furthermore, YYHs inhibited the phosphorylation of p65 in total cell lysates and the translocation of p65 from the cytoplasm to the nucleus. In general, YYHs contributed to ameliorate inflammatory response through TLR4/MD-2 mediating NF-kB pathway. This study provides novel insights into the mechanisms of YYHs as anti-inflammatory agents to LPS-mediated inflammatory response. Moreover, further studies needs to be verified in animal models.

\section{Abbreviations}

HPLC-MS/MS: High performance liquid chromatography-mass spectrometrymass spectrometry; IL-2: Interleukin-2; LPS: Lipopolysaccharide; NF-kB: Nuclear factor-KB; NO: Nitric oxide; TLR4/MD-2: Toll-like receptor 4/ myeloid differentiation factor-2; TNF-a: Tumor necrosis factor-a; YYHs: E.sagittatum of ethyl acetate extracts

\section{Acknowledgements \\ This research did not receive any specific grant from funding agencies in the public, commercial, or not-for-profit sectors.}

\section{Funding}

This research did not receive any specific grant from funding agencies in the public, commercial, or not-for-profit sectors.

\section{Availability of data and materials}

The datasets analyzed during the current study are available from the corresponding author on reasonable request.

\section{Authors' contributions}

The study was designed and carried out by NY and SJX. Experiment and data analysis was carried out by NY, DSW, YRZ and SJX. Drafting of the manuscript was done by NY and SJX. All authors read and approved the final manuscript.

Ethics approval and consent to participate

Not applicable.

Consent for publication

Not applicable.

\section{Competing interests}

The authors declare that they have no competing interests.

\section{Publisher's Note}

Springer Nature remains neutral with regard to jurisdictional claims in published maps and institutional affiliations.

\section{Author details}

${ }^{1}$ Department of Research and Development, ImVin Pharmaceutical Co., Ltd, 2 Fangcaodian Road, Guangzhou 510663, China. ${ }^{2}$ School of Pharmaceutical Sciences, Sun Yat-Sen University, Guangzhou 510006, China. ${ }^{3}$ Zhuhai Jizhu Small and Medium Enterprises Advanced Technology Research Institute, Zhuhai College of Jilin University, Zhuhai 519041, China.

Received: 7 May 2018 Accepted: 25 October 2018

Published online: 13 November 2018

\section{References}

1. Su YW, Chiou WF, Chao AH, Lee MH, Chen CC, Tsai YC. Ligustilide prevents LPS-induced iNOS expression in RAW 264.7 macrophages by preventing ROS production and down-regulating the MAPK, NF-KB and AP-1 signaling pathways. Int Immunopharmacol. 2011;11:1166-72

2. Heumann D, Roger T. Initial responses to endotoxins and gram-negative bacteria. Clin Chim Acta. 2002;323:59-72.

3. Ryu JK, Kim SJ, Rah SH, Park BS, Yoon TY, Kim HM. Reconstruction of LPS transfer cascade reveals structural determinants within LBP, CD14, and TLR4MD2 for efficient LPS recognition and transfer. Immunity. 2017:46:38-50.

4. Liu D, Cao G, Han L, Ye Y, SiMa Y, Ge W. Flavonoids from Radix Tetrastigmae inhibit TLR4/MD-2 mediated JNK and NF-KB pathway with antiinflammatory properties. Cytokine. 2016;84:29-36.

5. Coussens LM, Werb Z. Inflammation and cancer. Nature. 2002;420:860-7.

6. Akiyama H, Barger S, Barnum S, Bradt B, Bauer J, Cole GM, Cooper NR, Eikelenboom P, Emmerling M, Fiebich BL, Finch CE, Frautschy S, Griffin WST, Hampel H, Hull M, Landreth G, Lue LF, Mrak R, Mackenzie IR. Inflammation and Alzheimer's disease. Neurobiol Aging. 2000;21:383-421.

7. Dandona P, Aljada A, Bandyopadhyay A. Inflammation: the link between insulin resistance, obesity and diabetes. Trends Immunol. 2004;25:4-7.

8. Viatour P, Merville MP, Bours V, Chariot A. Phosphorylation of NF-kB and $1 k B$ proteins: implications in cancer and inflammation. Trends Biochem Sci. 2005;30:43-52. 
9. Guha M, Mackman N. LPS induction of gene expression in human monocytes. Cell Signal. 2001;13:85-94.

10. Schmitz ML, Mattioli I, Buss H, Kracht M. NF-kB: a multifaceted transcription factor regulated at several levels. Chembiochem. 2004;5:1348-58.

11. Chen XJ, Ji H, Zhang QW, Tu PF, Wang YT, Guo BL, Li SP. A rapid method for simultaneous determination of 15 flavonoids in Epimedium using pressurized liquid extraction and ultra-performance liquid chromatography. J Pharm Biomed Anal. 2008;46:226-35.

12. Chinese pharmacopoeia commission. Pharmacopoeia of the People's Republic of China. China, Beijing. 2015.

13. Cho WK, Weeratunga P, Lee BH, Park JS, Kim CJ, Ma JY, Lee JS. Epimedium koreanum Nakai displays broad spectrum of antiviral activity in Vitro and in Vivo by inducing cellular antiviral state. Viruses. 2015;7:352-77.

14. Sun JH, Ruan XJ, Wang LN, Liang S, Li XP. Study on the Antinociceptive effects of herba Epimedium in mice. Evid-based Compl Alt. 2015. https://doi.org/10.1155/2015/483942.

15. Shen $C Y$, Jiang JG, Yang L, Wang DW, Zhu W. Anti-aging active ingredients from herbs and nutraceuticals used in TCM: pharmacological mechanisms and implications for drug discovery. Br J Pharmacol. 2017;174:1395-425.

16. You SH, Jang M, Kim GH. Antioxidant activity and protective effect on PC12 against $\mathrm{H}_{2} \mathrm{O}_{2}$ of Epimedium koreanum. FASEB J. 2017;31(Suppl 1). https://www.fasebj.org/doi/abs/10.1096/fasebj.31.1_supplement.llb190.

17. Wang C, Feng L, Su J, Cui L, Liu D, Yan J, Ding C, Tan X, Jia X. Polysaccharides from Epimedium koreanum Nakai with immunomodulatory activity and inhibitory effect on tumor growth in LLC-bearing mice. J Ethnopharmacol. 2017;207:8-18

18. Li F, Du BW, Lu DF, Wu WX, Wongkrajang K, Wang L, Pu WC, Liu CL, Liu HW, Wang MK, Wang F. Flavonoid glycosides isolated from Epimedium brevicornum and their estrogen biosynthesis-promoting effects. Sci Rep. 2017;7:7760.

19. Ma H, He X, Yang Y, Li M, Hao D, Jia Z. The genus Epimedium: an ethnopharmacological and phytochemical review. J Ethnopharmacol. 2011:134:519-41.

20. Chen WF, Wu L, Du ZR, Chen L, Xu AL, Chen XH, Teng JJ, Wong MS Neuroprotective properties of icariin in MPTP-induced mouse model of Parkinson's disease: involvement of PI3K/Akt and MEK/ERK signaling pathways. Phytomedicine. 2017:25:93-9.

21. Chi L, Gao W, Shu X, Lu X. A natural flavonoid glucoside, icariin, regulates Th17 and alleviates rheumatoid arthritis in a murine model. Mediat Inflamm. 2014. https://doi.org/10.1155/2014/392062.

22. Liu M, Xu H, Ma Y, Cheng J, Hua Z, Huang G. Osteoblasts proliferation and differentiation stimulating activities of the main components of Epimedii folium. Pharmacogn Mag. 2017;13:90-4.

23. Wang L, Li Y, Guo Y, Ma R, Fu M, Niu J, Gao S, Zhang D. Herba Epimedir: an ancient Chinese herbal medicine in the prevention and treatment of osteoporosis. Curr Pharm Design. 2016;22:328-49.

24. Tang X, Nian H, Li X, Yang Y, Wang X, Xu L, Shi H, Yang X, Liu R. Effects of the combined extracts of Herba Epimedii and Fructus Ligustrilucidi on airway remodeling in the asthmatic rats with the treatment of budesonide. BMC Complement Altern Med. 2017;17:380-91.

25. Lee HS, Bilehal D, Lee GS, Ryu DS, Kim HK, Suk SH, Lee DS. Anti-inflammatory effect of the hexane fraction from Orostachys japonicus in RAW 264.7 cells by suppression of NF-KB and PI3K-Akt signaling. J Funct Foods. 2013;5:1217-25.

26. Kang YJ, Lee MW, Kang SS. Flavonoids from Epimedium koreanum. J Nat Prod. 1991;54:542-6.

27. Sun $X$, Deng X, Cai W, Li W, Shen Z, Jiang T, Huang J. Icariin inhibits LPSinduced cell inflammatory response by promoting GRa nuclear translocation and upregulating GRa expression. Life Sci. 2018:195:33-43.

28. Li L, Sun J, Xu C, Zhang H, Wu J, Liu B, Dong J. Icariin ameliorates cigarette smoke induced inflammatory responses via suppression of $\mathrm{NF}-\mathrm{kB}$ and modulation of GR In Vivo and In Vitro. PLoS One. 2014. https://doi.org/10. 1371/journal.pone.0102345

29. Wang GQ, Li DD, Huang C, Lu DS, Zhang C, Zhou SY, Liu J, Zhang F. Icariin reduces dopaminergic neuronal loss and microglia-mediated inflammation in Vivo and in Vitro. Front Mol Neurosci. 2018;10:441-51.

30. Deng Y, Long L, Wang K, Zhou J, Zeng L, He L, Gong Q. Icariside II, a broadspectrum anti-cancer agent, reverses beta-amyloid-induced cognitive impairment through reducing inflammation and apoptosis in rats. Front Pharmacol. 2017:8:39-50

31. Yin $L L$, Lin $L L$, Zhang L, Li L. Epimedium flavonoids ameliorate experimental autoimmune encephalomyelitis in rats by modulating neuroinflammatory and neurotrophic responses. Neuropharmacology. 2012;63:851-62.
32. Bredt DS. Endogenous nitric oxide synthesis: biological functions andpathophysiology. Free Radic Res. 1999;31:577-96.

33. Suematsu N, Tsutsui H, Wen J, Kang D, Ikeuchi M, Ide T, Hayashidani S, Shiomi T, Kubota T, Hamasaki N, Takeshita A. Oxidative stress mediates tumor necrosis factor-alpha-induced mitochondrial DNA damage and dysfunction in cardiac myocytes. Cirulation. 2003:107:1418-23.

34. Balkwill F. TNF-alpha in promotion and progression of cancer. Cancer Metast Rev. 2006;25(3):409-16.

35. Tripathi $P$, Tripathi $P$, Kashyap $L$, Singh $V$. The role of nitric oxide in inflammatory reactions. FEMS Immunol Med Microbiol. 2007;51:443-52.

36. Kawanishi S, Ohnishi S, Ma N, Hiraku Y, Murata M. Crosstalk between DNA damage and inflammation in the multiple steps of carcinogenesis. Int J Mol Sci. 2017;18:1808-20.

37. Kikuchi-Maki A, Yusa S, Catina TL, Campbell KS. KIR2DL4 is an IL-2-regulated NK cell receptor that exhibits limited expression in humans but triggers strong IFN-gamma production. J Immunol. 2003;171:3415-25.

38. Park BS, Song DH, Kim HM, Choi BS, Lee H, Lee JO. The structural basis of lipopolysaccharide recognition by the TLR4-MD-2 complex. Nature. 2009; 458:1191-5.

39. Xing J, Li R, Li N, Zhang J, Li Y, Gong P, Gao D, Liu H, Zhang Y. Antiinflammatory effect of procyanidin B1 on LPS-treated THP1 cells via interaction with the TLR4-MD-2 heterodimer and P38 MAPK and NF-KB signaling. Mol Cell Biochem. 2015;407:89-95.

40. Chen YF, Shiau AL, Wang SH, Yang JS, Chang SJ, Wu CL, Wu TS. Zhankuic acid a isolated from Taiwanofungus camphoratus is a novel selective TLR4/ MD-2 antagonist with anti-inflammatory properties. J Immunol. 2014;192: $2778-86$.

41. He X, Wei Z, Zhou E, Chen L, Kou J, Wang J, Yang Z. Baicalein attenuates inflammatory responses by suppressing TLR4 mediated NF-KB and MAPK signaling pathways in LPS-induced mastitis in mice. Int Immunopharmacol. 2015;28:470-6.

42. Wang Y, Qian Y, Fang Q, Zhong P, Li W, Wang L, Fu W, Zhang Y, Xu Z, X. Li, Liang G. Saturated palmitic acid induces myocardial inflammatory injuries through direct binding to TLR4 accessory protein MD2. Nat Commun. 2017; 8:13997.

43. Wang J, Liu YT, Xiao L, Zhu L, Wang Q, Yan T. Anti-inflammatory effects of apigenin in lipopolysaccharide-induced inflammatory in acute lung injury by suppressing COX-2 and NF-KB pathway. Inflammation. 2014;37:2085-90.

44. Lai Jl, Liu YH, Liu C, Qi MP, Liu RN, Zhu XF, Zhou QG, Chen YY, Guo AZ, Hu CM. Indirubin inhibits LPS-induced inflammation via TLR4 abrogation mediated by the NF-KB and MAPK signaling pathways. Inflammation. 2017;40:1-12.

Ready to submit your research? Choose BMC and benefit from:

- fast, convenient online submission

- thorough peer review by experienced researchers in your field

- rapid publication on acceptance

- support for research data, including large and complex data types

- gold Open Access which fosters wider collaboration and increased citations

- maximum visibility for your research: over $100 \mathrm{M}$ website views per year

At $\mathrm{BMC}$, research is always in progress.

Learn more biomedcentral.com/submissions 